\title{
FBI forensics tries mtDNA
}

Although forensics specialists at the US Federal Bureau of Investigation (FBI, Washington, DC) have been studying the utility of mitochondrial (mt) DNA for several years, they recently added judicial weight to this technology by taking some specific results into a Tennessee courtroom. There, mtDNAbased analysis is being used for the first time as evidence in a criminal proceeding-specifically, as part of a rape-and-murder trial.

Mitochondrial DNA offers several potential advantages over cellular DNA when it comes to forensic analyses, experts say. For one, mtDNA is present in several hundreds of copies per cell -a distinct advantage when dealing with scarce forensic samples. According to Paul Debenham, chief executive at University Diagnostics (London), mtDNA analysis is a specialist approach applied largely to compacted tissues with a paucity of usable cells. The analysis of skeletal remains using mtDNA both in forensics and in anthropology is one prime area of application. The US military has been using such DNA analysis to identify the remains of military personnel, and this tech- nology also was used to examine the bones of Czar Nicholas II of Russia.

In the Tennessee criminal proceeding, the sample consisted of hairs from the assailant found on the body of the four-year-old victim, mtDNA from which matched mtDNA

\section{Mitochondrial DNA offers} several potential advantages over cellular DNA when it comes to forensic analyses, experts say.

obtained from a hair sample obtained from the 27-year-old man on trial. Paul Ferrara of the Virginia Bureau of Forensic Science (Richmond, VA), explained that mtDNA is especially helpful when single hairs with no root matter or associated epithelial cells are the only DNA evidence available. Usually, however, nuclear DNA is preferable because either PCR sites or RFLP patterns give a more robust (more likely to be unique) identity. "For forensic purposes, mtDNA analysis adversely affects individualization issues because it has less discriminating power than RFLP patterns. But for the purpose of identification, it still can provide strong evidence, especially if the crime scene evidence is limited to single hairs."

Another advantage, albeit for addressing very different questions through forensic analysis, is that mtDNA is inherited maternally, meaning that it can prove particularly useful for determining mother-child and sibling-sibling relationships. Conversely, however, the maternal inheritance of mtDNA also means that the technique cannot distinguish the sample of a suspect from that of his or her maternal relations: Mother, grandmother, sister, brother, or maternal cousins. Indeed, its linear maternal transmission means that the number of different types of mtDNA is limited.

Jeffrey L. Fox

\section{Another genome, another kingdom, another set of surprises}

A US team of researchers announced in September the DNA sequence of yet another genome, marking the first time that a microorganism within the Archaea has been so analyzed. Once again, that team from several universities and other private and federal research institutions included Craig Venter of the Institute for Genomic Research (TIGR, Rockville, MD), who has now chalked up four microbial genomes in barely more than a year. Not only does this genome contain surprises of fundamental interest to biologists, he, his collaborators, and federal supporters say it may harbor DNA sequence data about thermostable enzymes of commercial value in various biotechnology applications.

The latest analyte in the genomesequencing cavalcade is Methanococcus jannaschii, a methane-producing thermophile that Holger Jannasch of Woods Hole Oceanographic Institute (Woods Hole, MA) and his collaborators discovered more than a decade ago at the base of a Pacific Ocean thermal vent. Since then, both small and large organisms obtained from such habitats have provided biologists with a steady stream of surprises. One delectable surprise from the $M$. jannaschii DNA sequence analysis is that "two-thirds of the genes do not look like anything we've ever seen in biology before,"
Venter says. The microorganism carries 1760 genes contained on a $1.6 \mathrm{Mb}$ chromosome and two smaller plasmids, one about $16 \mathrm{~kb}$ and the other about $55 \mathrm{~kb}$.

\section{The latest analyte in the} genome-sequencing cavalcade is Methanococcus jannaschii, a methane-producing thermophile.

Little doubt seems to remain about the autonomy of the Archaea, a fundamental reconfiguration of biology that was first proposed in 1979 by Carl Woese of the University of Illinois (Champaign-Urbana, IL). Woese, who was a part of the team effort to analyze the DNA of $M$. jannaschii, contends that it and other such organisms belong to a separate kingdom or domain, one that is set apart from the more familiar branchesconsisting of bacteria, plants, and animals that biologists have been studying for many, many decades. The latest DNA sequencing results indicate clearly that members of the Archaea represent "separate and distinct life forms," Venter adds.

Besides being separate and distinct, these life forms may also someday. prove profitable, suggests Hazel O'Leary, Secretary of the Department of Energy (DOE, Washington, DC), which funded the $M$. jannaschii sequencing effort. "The biotechnology industry is watching carefully to see how this breakthrough can help develop new sources of renewable energy, clean up the environment, and improve human health," she says.

Because the optimal growth temperature for this microorganism is $85^{\circ} \mathrm{C}$, its enzymes, like those of other thermophiles, are likely to be thermally stable and therefore of potential value in various industrial settings. Moreover, although difficult to grow, this microorganism produces methane, a useful energy source and chemical feedstock. In addition, DOE officials point out, $M$. jannaschii produces unusual metal-binding proteins for exporting toxic chemicals from the cell. Such proteins might eventually prove useful for concentrating and cleaning up some of the toxic components now found in complex mixtures at the hundreds of waste sites that DOE is required to remediate.

Jeffrey L. Fox 